\title{
On the Powdery Mildew of Flax.
}

\author{
By
}

\section{Yasu Homma.}

In the course of her study on the Japanese Erysiphaceae, the writer has noticed that there are two different species of powdery mildew parasitic on the cultivated flax in our country.

On September 15, 1922, one of these species was first found on the leaves and stems of flax cultivated in a green-house of our University. Under a microscope, it appeared to be a conidial stage of the genus, Erysiphe. The characters of the fungus are given in the following paragraph.

White mycelium develops not only on both surfaces of the leaf, but also on the stem and peduncle, from which small ellipsoidal or globular haustoria are sent into the epidermal cells of the host. The

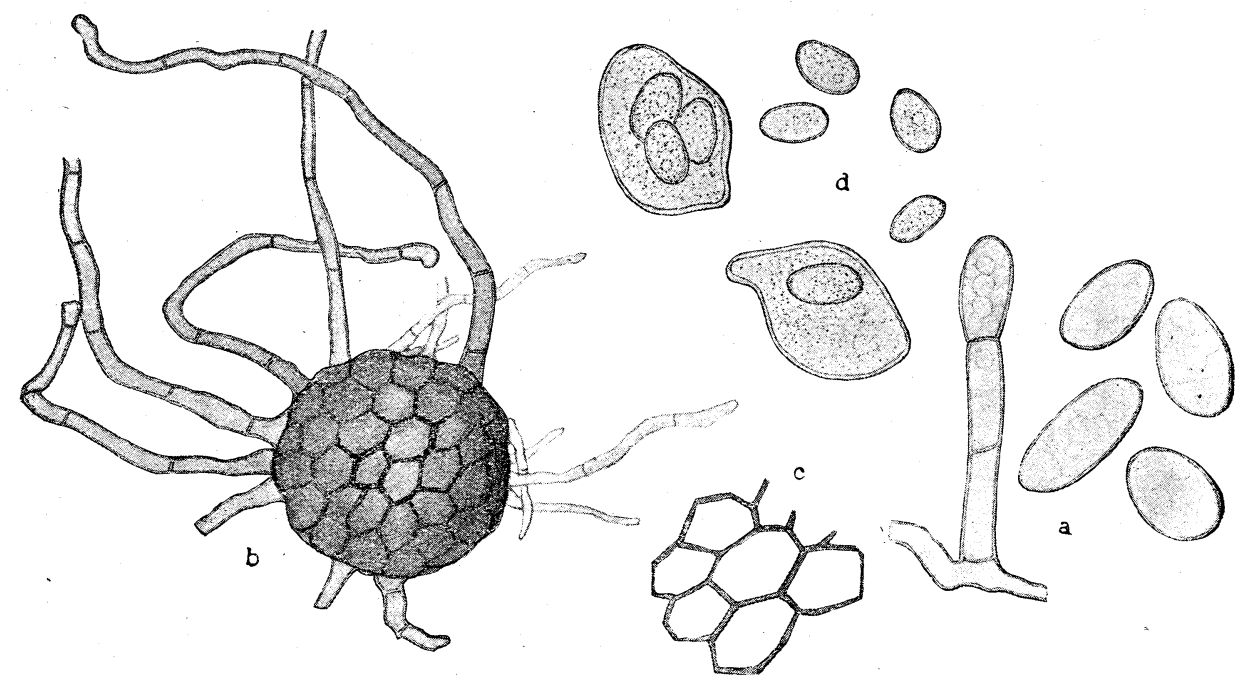

Fig. 1. Erysiphe Polygoni DC. on Linum usitatissimum L.

a. Conidia and conidiophore, $\times 350$, b. Perithecium, $\times 60$,

c. Cells of perithecial wall, $\times 350$, d. Asci and ascospores, $\times 350$.

conidia are produced in a chain, but look as if they are borne singly at the tip of the conidiophore. They are ellipsoidal or oblong-ellipsoidal in shape. (Fig. 1, a) The size of the conidia is $30.0-38.4 \times 19.4-24.0 \mu$, the measurements being made on the fresh conidia taken from the 
leaves and stems, and mounted in water. The conidiophores are one or two septate, reaching $62.4 \mu$ in length. About two months later, (November 11), a small number of perithecia were produced on the same plants left in the green-house. The white mycelium is evanescent, disappearing before the perithecia reach their maturity. The size of the perithecia is $91-105 \mu$ in diameter, and the cells of the perithecial wall are angular in outer view and 16.8-19.2 $\mu$ across. The appendages are about 8 in number, measuring 168-217 $\mu$ in length, with 5 to 7 septa, brown-colored toward the base. (Fig. 1, b) Usually each perithecium contains six asci. The asci are ovate in shape, with short stalk, colorless, 48.0-55.2 $\times 24.0-31.12 \mu$. Each ascus contains two or three (rarely one) ascospores. The ascospores are ellipsoidal, hyaline, 18.0-20.4 $\times 9.8-12.0 \mu$ in size. (Fig. 1, d)

From the above mentioned characters of the conidia and perithecia, the writer concluded that the present fungus is identical with Erysiphe Polygoni DC. The fact was reported by the writer ${ }^{1)}$ in May, 1927. It

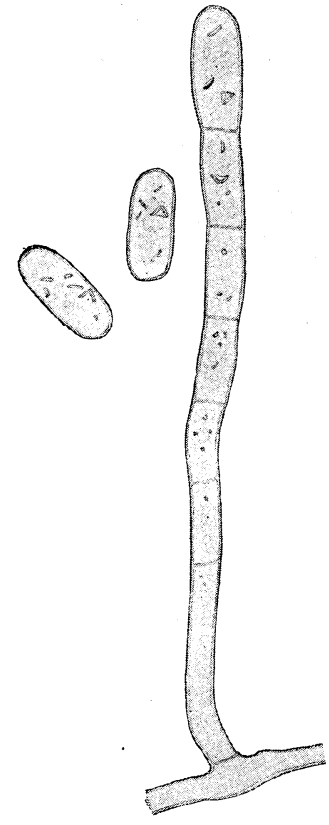

Fig. 2. Oidium lini ŠKorIĆ on Linum usitatissimum $\mathrm{L}$. Conidia and conidiophore. $(\times 350)$ was the first record on the powdery mildew of the flax in our country.

On September 30, 1926, the second species was found on the leaves and stems of flax grown in the same green-house. No perithecia have been produced up to the present time, but the character of the conidia differs distinctly from that of the first species. The present fungus has the following characters.

Mycelium is formed on both surfaces of the leaf and often on the stem. Conidia are produced abundantly presenting a white powdery appearance and they are formed in a chain of two or three. They are oblong or cylindrical-oblong in shape, containing the fibrosin bodies of well-developed special forms. (Fig. 2) The size of conidia is $26.4-36.0 \times 12.0-14.4 \mu$, mostly larger than $27 \mu$ in length and $12 \mu$ in width.

These characters of the fungus in question coincide essentially with the description of Oidium lini given by V. Škorić. ${ }^{2)}$ His des-

1) Horticulture (Engei), Vol. XIX, p. 13, 1927. (In Japanese).

2) Annales pro Experimentis Foresticis, I, p. 108, 1926. 
cription of Oidium lini is as follows : "Mycelio arachnoides, effuso, albo et persistenti, conidiis oblongis, apice obtusis, duobus vel tribus concatenatis, $26-41 \times 12-15 \mu$." The conidia of our fungus are a little smaller in size than those of Croatia, but as ŠKonIć stated, the present fungus clearly differs from the conidial form of Erysiphe Polygoni in the size, shape, and character of the conidia, and especially in the presence of the fibrosin bodies. Although the perithecial stage of the present fungus has never been observed either in Europe or Japan, there is no doubt of its being a species of Sphaerotheca from the general characters of its conidia. At present, the specific name, Oidium lini ŠKORIĆ must be used for the second fungus.

In July, 1927, E. S. SALMON and W. M. WARE ${ }^{1)}$ published a paper on "the mildew of flax", after the examination of the specimen which was collected by A. W. HENRy in the green-house of the Botany Department of the University of Cambridge in England. These authors said that the fungus occurs on both surfaces of the leaf and more densely on the main stem, that the upright branches of the white mycelium bear oblong conidia which are produced either singly at the tip or in a chain of two or three, and that the size of the conidia varies from $31-40 \times 12-16 \mu$, (average size being $34 \times 14 \mu$ ). An illustration of the conidiophores bearing short chains of conidia was given. After citation of many papers (P. MAGnus ${ }^{2)}$, G. Lindad ${ }^{3)}$, De THUEMAN ${ }^{4)}, \mathrm{F}^{\text {. }}$. STRANAK ${ }^{5)}$ and V. ŠKorIĆ(i) $)$, they concluded: "it appears, therefore, very doubtful whether the powdery mildew of the flax has ever been found in the perithecial stage, and until this has been done, its name can not be determined with certainty. All that can be said at present is that it agrees in its characters with the conidial stage of Erysiphe Polygoni, and may possibly prove to be that species."

As above stated, the writer has found two different species of the Erysiphaceae parasitic on the cultivated flax in Japan. The first species is Erysiphe Polygoni DC. which could be determined with certainty from the characters of its conidial and perithecial stages, but it differs clearly from the powdery mildew reported by SALMON and WARE. The characters of the latter species agree with those of Oidium lini ŠKorIć, as they have stated, and moreover with those of our second

1) Gard. Chron. LXXXII, p. 34-35, 1927.

2) Ber. Natur. Ver. Inn. XXIV, p. 18, 1898.

3) Pilze Deutsch1. VIII, p. 80, 1907.

4) Grevillea, VIII, p. 49, 1879-80.

5) Ochrana Rostlin, VI, 3, p. 37, 1926.

6) 1.c. 
species. The question whether Oidium lini ŠKorIć is the conidial stage of a new species or an already well known species of Sphaerotheca can only be settled by the study of its perithecial stage.

March 25, 1928.

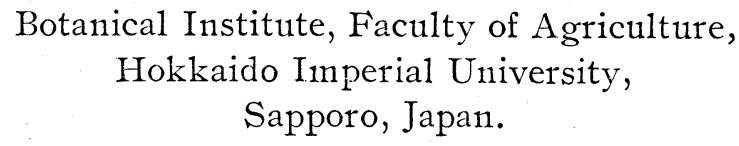

\section{羊齫類二於ヶル中心柱ノ分類學上ノ價值二就テ}

(第 三 報)

早田文藏

Hayata, B. - On the Systematic Importance of the Stelar System in the Filicales, III.

すげしだ Amesium Sıszkii HAY.*=Anesium Sasakii HaY. 本種八臺灣新高 山一萬千尺ノ高距二產シ、通常族生シテ岩石ノ間＝固着ス、今包佐ふ木舜一氏 $=ヨ リ$ テ初メテ發見セラレタル新種ナリ、ソノ外形 Monogrumme (Hoorer-BAKER Syn. Fil. p. 374) =近似シ.殊 = Eumonogramme =屬スル $M$. dareicarpa Ноок. Sp. Fil. V. P. 121，t. 288 A. 二酷似ス、然レドモ本種八一層ノ細胞ヨリ成儿胞子囊

* Amesium Sasakii Hay. Sp. nov. Filix parva, habitu caricis inter saxa sicca in fasciculis densis crescens. Rhizoma ascendento-procumbens teres $2 \mathrm{~mm}$. in diametro sectionis squamis et reliquis stipitum densissime obtectum; squamis nigrocastaneis lineari-lanceolatis basi haud contractis $2 \frac{1}{2} \mathrm{~mm}$. longis $\frac{1}{3} \mathrm{~mm}$. latis apice acuminatis margine setulis brevissimis remotissime instructis, reliquis stipitum fuscocastaneis $910 \mathrm{~mm}$. longis teretibus $\frac{1}{2} \mathrm{~mm}$. in diametro sectionis vix glabris. Dictyostele radialis vestigio radicis uno e basi lacunae folii oriundo, fasciculo vasorum vestigii folii uno supra vestigium radicis superposito, lacuna folii oblongo-fusiformi. Folia viridia versus apicem rhizomatis fasciculatim disposita cum stipitibus $10-20 \mathrm{~cm}$. 1onga linearia. Stipes suberectus frondem 2-4 plo in longitudine aequans plus minus complanatus supra secus medium sulcatus subtus ad costam elevatus utroque latere costae sulcatus subglaber, partibus basilaribus usque ad 7-8 $\mathrm{mm}$. castaneo-coloratis persistentibus, partibus superioribus viridibus deciduis. Frons lineari-lanceolata apice acuminata basi longe sensimque ad petiolum attenuata $3-4 \mathrm{~cm}$. longa $1 \frac{1}{2}-2 \mathrm{~mm}$. lata utraque facie glabra supra 3-5-sulcata subtus copiose sorifera, margine paucissime laciniatolobata, lobis utroque latere marginis frondis $1-2$ linearibus $2-5 \mathrm{~mm}$. longis $\frac{1}{3} \mathrm{~mm}$. latis supra medio sulcatis apice setuliformibus. Sori lineares $5 \mathrm{~mm} .-10 \mathrm{~mm}$. longi approximati, indusiis membranaceis fulvescentibus margine subintegris.

НАв. Monte Morrison at 11000 ped. alt. inter saxa sicca crescens, 1eg. R. KANEHIRA et S. SASAKr, Oct. anno 1927. 